\title{
An analysis of the climatic parameters needed for Tuber melanosporum cultivation incorporating data from six continents
}

\section{Thomas PW ${ }^{1}$ \\ ${ }^{I}$ Mycorrhizal Systems Ltd, Unit 4A, Popples Close Farm, HX7 7PG, UK. Paul@PlantationSystems.com}

Thomas PW 2014 - An analysis of the climatic parameters needed for Tuber melanosporum cultivation incorporating data from six continents. Mycosphere 5(1), 137-142, Doi $10.5943 /$ mycosphere/5/1/5

\begin{abstract}
Climatic parameters associated with sites producing Tuber melanosporum fruiting bodies within countries that have a natural population of Tuber melanosporum and those without such records were compared. Represented continents include Africa, Asia, Australia, Europe, North America and South America with only Antarctica remaining outside the scope of this study. The compiled data presents a broader than expected range of climatic parameters that are suitable for truffle cultivation. Development of fruiting orchards in countries that do not have a history of natural populations has expanded our understanding of the suitable climatic ranges of this species. Truffle cultivation is successful in areas that have a lower temperature and higher rainfall levels than expected. The data compiled here is of use to truffle scientists as well as cultivators in choosing suitable locations for a plantation.
\end{abstract}

Key words - climate - orchard - rainfall - temperature - truffle

\section{Introduction}

Tuber spp. (truffles) are a group of hypogeous fungi that include some of the most revered of all cultivatable foods. The species Tuber melanosporum is highly regarded for its culinary properties and is the most widely cultivated of all the Tuber species. These ascomycetes are an obligate mycorrhizal species, growing in association with a range of woody plant species. To cultivate Tuber melanosporum, tree species are inoculated with the fungi and once the mycohrriza is established, these young tree saplings are planted into carefully controlled field sites. Although the exact soil nutrient requirements are not yet agreed, more basic soil conditions needed for truffle cultivation, such as structure and $\mathrm{pH}$ are widely accepted (Chevalier \& Frochot 1997, Thomas 2012).

The described approach to truffle cultivation is widely employed throughout areas of Europe in which Tuber melanosporumoccurs naturally and is now also successful in other regions of the world (Hall et al. 2007). Cultivation of this species outside of Europe has principally focused on regions perceived to have a similar climatic profile to that of its natural range within France (after Delmas 1978), although this species grows naturally across a number of other European countries. The often-cited ideal climatic variables are based on a relatively small, and geographically limited, dataset.

Using data from naturally producing Tuber melanosporum areas within Europe, in order to ascertain the climatic suitability of new regions for cultivation, may be an unnecessarily limiting 
approach. The natural distribution of Tuber melanosporumin Europe was reduced to a number of refuges during glacial events (Bertault et al. 1998) and since the last glaciation, the expansion of this species range has been restricted by a number of variables including the expansion of their host tree geographic range (Murat et al. 2004). Thus, utilizing the climatic parameters of naturally producing Tuber melanosporum areas as a means of identifying suitable areas for cultivation may be an unnecessarily restrictive approach.

Truffle cultivation has now spread to, and is successful in, a number of countries worldwide in which the truffle species has never, to our knowledge, occurred naturally. Collecting data from these sites, as well as a wide range of European data, may present a broader understanding of the acceptable climatic parameters for cultivation.

Here, data is collated from a range of wild and cultivated Tuber melanosporum, producing sites, spanning six continents, in order to present a clear picture of the required climatic parameters of this species. The resulting data will allow a more informed analysis of the potential of a region to produce fruiting bodies.

\section{Materials \& Methods}

For the analysis of the climatic parameters needed for Tuber melanosporumsporocarp production, data was collated from a wide range of sites. Published records of sporocarp collection were identified and the documented locations of these sites were used to identify climatic parameters for each individual site. The climatic data was sourced from a wide range of largely government-funded metrological logging stations. Data was collected from Africa, America, Asia, Australasia, Europe and South America. The sites incorporate those from countries that have a historical record of natural Tuber melanosporum fruiting and those in which Tuber melanosporum does not occur naturally. Locations and represented counties include Spain (Parladé et al. 2013,Suz et al. 2006), France (Le Tacon et al. 2013, Napoli et al. 2010, Pépinière 2004, Shaw et al. 1996), Australia (Bradshaw 2005, Linde \& Selmes 2012), Italy (BaBaciarelli-Falini et al. 2006, Castrignanò et al. 2000, Lulli, et al. 1999), Canada (Shore 2013), USA (O’Neill 2007, Shore 2013), Israel (Turgeman et al. 2012), Chile (Cordero et al. 2011), Morocco (Khabar 2011) and New Zealand (Hall et al. 2007).

\section{Results and Discussion}

The black truffle, Tuber melanosporum, is often viewed as occupying a very distinct and rigid environmental niche. However, the compiled data from sites where Tuber melanosporum is fruiting displays a remarkable degree of climatic variation. For example, data compiled from six continents displays fruiting across a range of climatic variables with a $868 \mathrm{~mm}$ variation in winter rainfall and a $6.6^{\circ} \mathrm{C}$ variation in annual average temperature (Table 1). This range is surprising when the classical view of a distinct and narrow ecological niche is considered (after Delmas 1978). Further, for a species that is often regarded as slow growing and poorly competitive, with a low level of genetic diversity (Bertault et al. 1998), the presented geographic spread is remarkable. Based on an appreciation of the organoleptic properties, cultivation has been so successful that the only continent in this study not represented is Antarctica.

The development of plantations in countries that do not have a history of natural Tuber melanosporumpopulations has been successful in areas with some climatic conditions similar to those in areas that have a history of natural fruiting (Fig. 1). Comparisons between sites from countries that have historical populations of Tuber melanosporum and those that do not, revealed no significant difference in the annual average temperature $(T=0.0097, \mathrm{df}=33, \mathrm{p}>0.05)$, winter temperature $(T=1.9439$, df $=32, \mathrm{p}>0.05)$, mean summer rainfall $(T=0.9160$, df $24=, \mathrm{p}>0.05)$ or annual sunshine hours $(T=1.3952$, $\mathrm{df}=34, \mathrm{p}>0.05)$ (Fig. 1). This degree of similarity is expected. However, sites producing Tuber melanosporum in countries in which it did not previously naturally exist had significantly higher annual rainfall $(T=4.5165$, df $33=, p<0.05)(1032.65 \mathrm{~mm}$ vs $585.25 \mathrm{~mm})$ and mean winter rainfall $(T=3.9114$, df $24=, \mathrm{p}<0.05)$ (393.61mm vs 122.46) (Fig. 2.).An example of this expansion in parameters is the high winter rainfall region of Corvallis, USA 


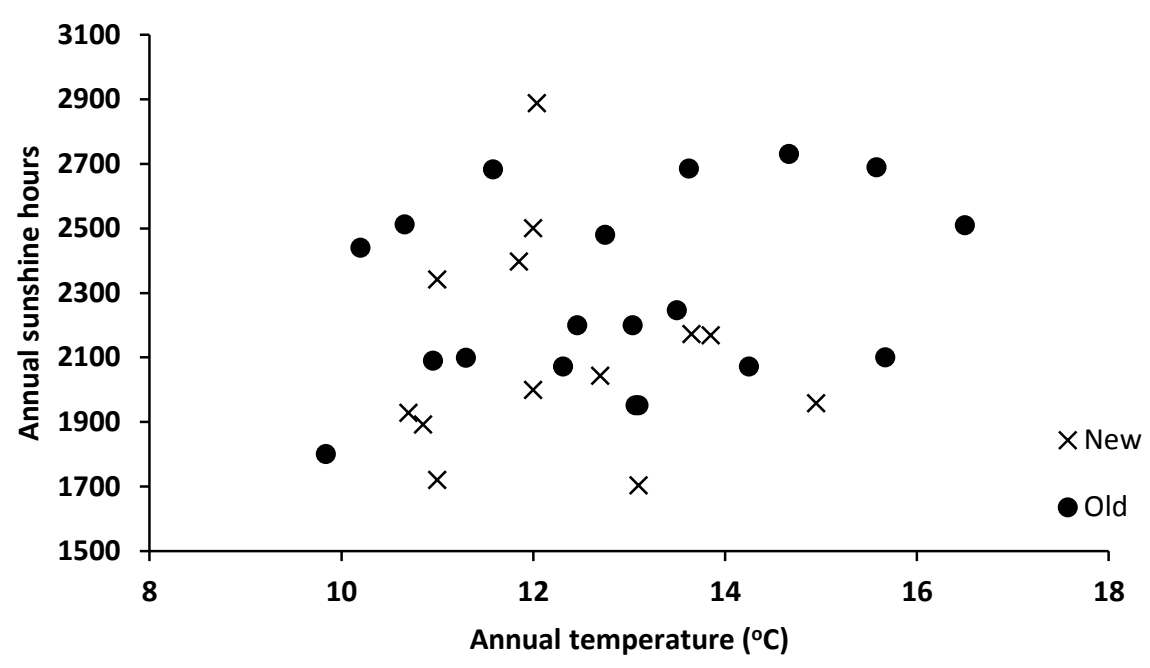

Fig. 1 Mean values of annual temperature $\left({ }^{\circ} \mathrm{C}\right)$ and annual sunshine hours from plantations in countries that have a history of Tuber melanosporum natural populations $(\mathrm{Old})$ and those that do not (New).

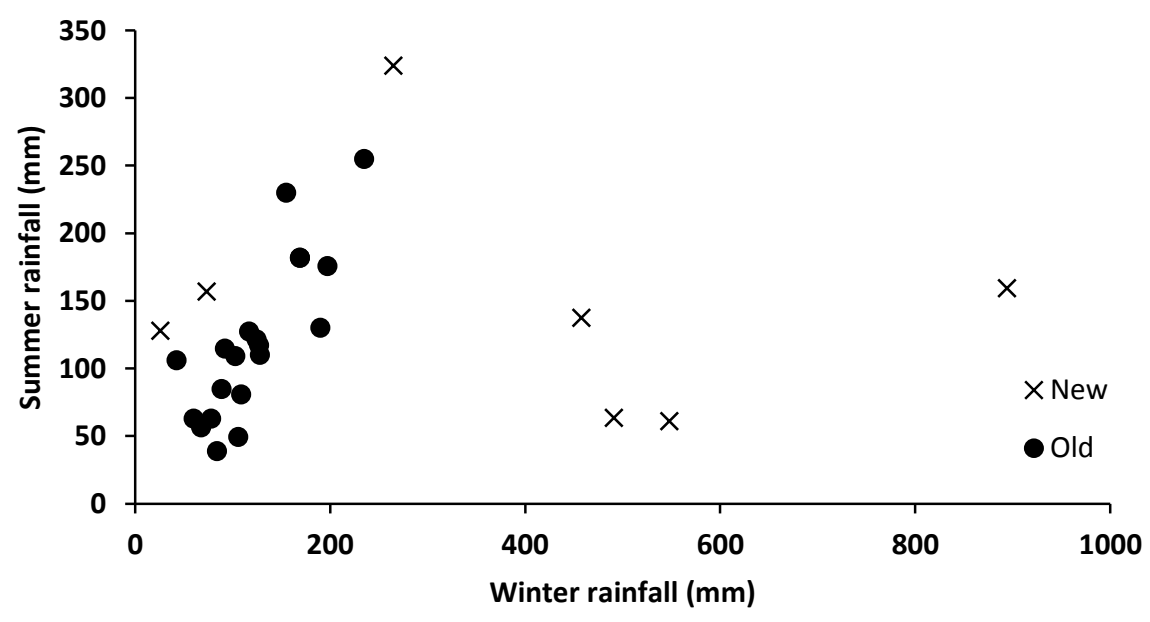

Fig. 2 Mean values of summer rainfall $(\mathrm{mm})$ and winter rainfall $(\mathrm{mm})$ from plantations in countries that have a history of Tuber melanosporum natural populations (Old) and those that do not (New).

(Shore 2013). Further, summer temperatures showed a clustered distribution (Fig. 3) with temperatures being lower $\left(18.98^{\circ} \mathrm{C}\right.$ vs $\left.21.73^{\circ} \mathrm{C}\right)$ in sites that do not have a history of natural Tuber melanosporum populations $(T=3.4877, \mathrm{df}=33, \mathrm{p}<0.05)$. These differences are displayed in figure 4. and have significantly expanded the range of conditions that we now know to be suitable for fruiting (Table 1.). This data is now a useful reference for scientists and truffle cultivators worldwide. 
Table 1 Climatic data compiled from sites that are producing Tuber melanosporum fruiting bodies. The data incorporates sites in Africa, Asia, Australia, Europe, North America and South America.

\begin{tabular}{llll}
\hline & Minimum & Maximum & Average \\
\hline Annual temperature $\left({ }^{\circ} \mathrm{C}\right)$ & 9.8 & 16.4 & 12.9 \\
Summer temperature $\left({ }^{\circ} \mathrm{C}\right)$ & 15.8 & 25.0 & 20.6 \\
Winter temperature $\left({ }^{\circ} \mathrm{C}\right)$ & 0.5 & 10.4 & 5.8 \\
Annual sunshine hours & 1704 & 2888 & 2226 \\
Annual rainfall $(\mathrm{mm})$ & 288 & 1788 & 777 \\
Summer rainfall $(\mathrm{mm})$ & 39 & 324 & 193 \\
Winter rainfall $(\mathrm{mm})$ & 26 & 894 & 127 \\
\hline
\end{tabular}

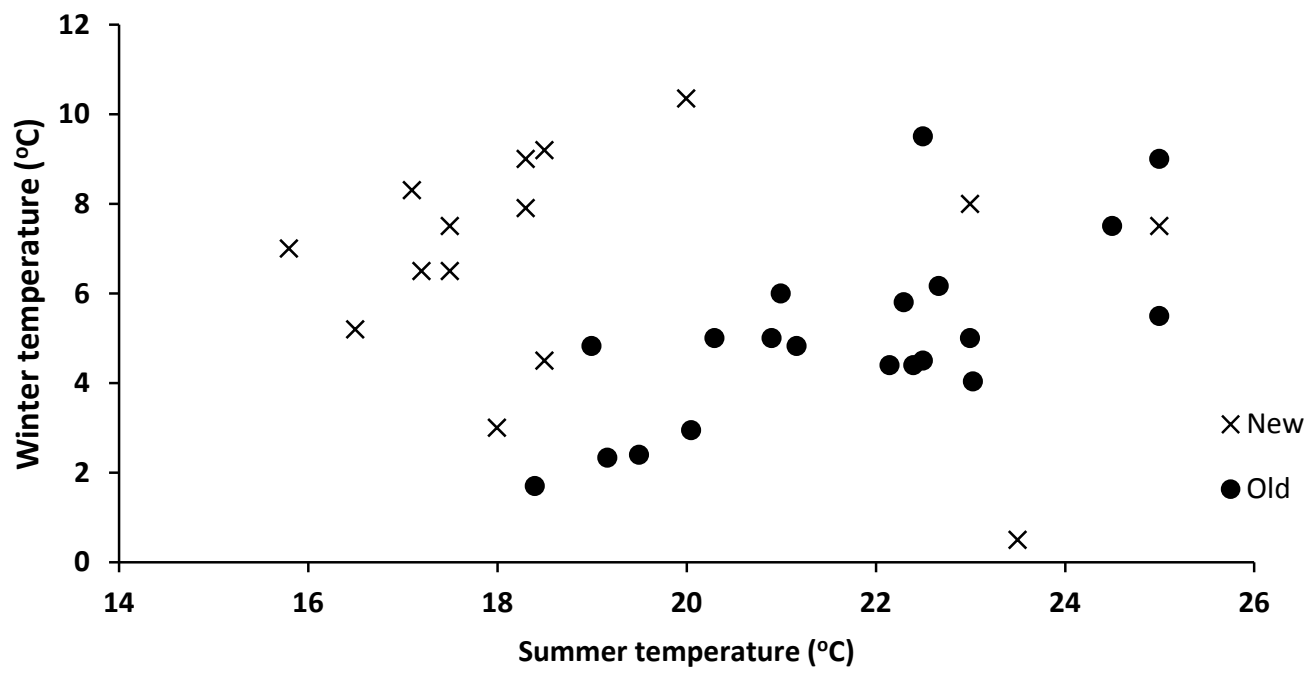

Fig. 3 Mean values of summer temperature $\left({ }^{\circ} \mathrm{C}\right)$ and winter temperature $\left({ }^{\circ} \mathrm{C}\right)$ from plantations in countries that have a history of Tuber melanosporum natural populations (Old) and those that do $\operatorname{not}(\mathrm{New})$.

Although the data presented in this study displays a wide range of climatic parameters suitable for cultivation, care must be taken in the interpretation. An ability to produce fruiting bodies is not an indication of ideal climatic parameters and modification within these boundaries, for example with irrigation, may be needed for optimal production (Chevalier \& Poitou 1990). Further, the interplay of variables must be considered. Although we know now that Tuber melanosporum can grow and fruit in higher rainfall areas and cooler summer temperatures than expected, it is possible that the combination of these two extremes may produce a scenario which is not conducive to fruit body formation. For successful cultivation, it must also be understood that even in ideal climatic parameters, there are many other areas of cultivation that must be considered, including the recent understanding of the heterothallic nature of Tuber melanosporum (Rubini et al. 2011, Thomas 2013). 
a)

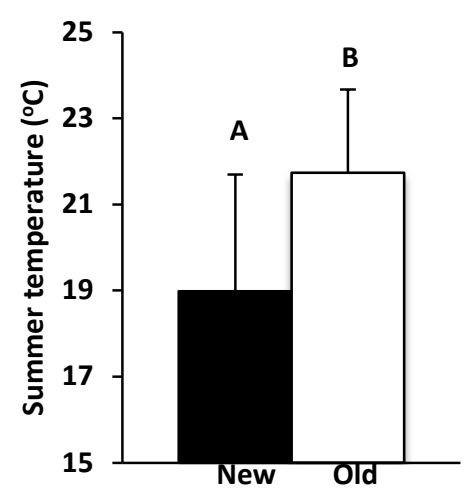

b)

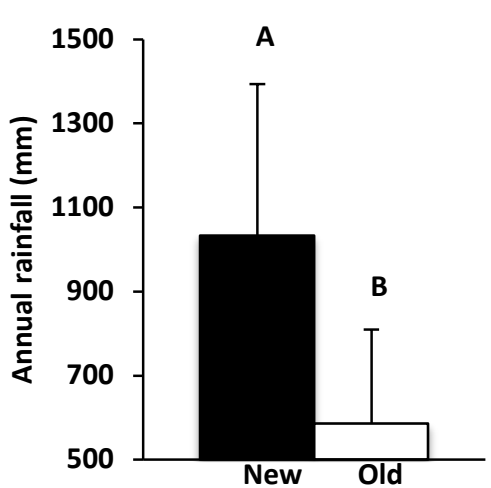

c)

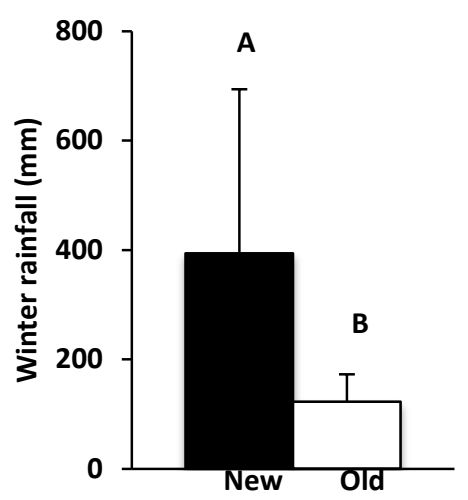

Fig. 4 Mean values \pm SE of summer temperature $\left({ }^{\circ} \mathrm{C}\right)(\mathrm{a})$, annual rainfall (b) and winter rainfall (c) from plantations in countries that have a history of Tuber melanosporum natural populations (Old) and those that do not (New). Bars followed by different letter codes are significantly different ( $\mathrm{t}-$ test, $\mathrm{p}<0.05)$.

\section{Acknowledgements}

Thanks to H. Sutton for assistance with data collection and interpretation.

\section{References}

BaBaciarelli-Falini L, Rubini A, Riccioni C, Paolocci F. 2006 - Morphological and molecular analyses of ectomycorrhizal diversity in a man-made $T$. melanosporum plantation: description of novel truffle-like morphotypes. Mycorrhiza 16, 475-484.

Bertault G, Raymond M, Berthomieu A, Callot G, Fernandez D. 1998 - Trifling variation in truffles. (Tuber melanosporumbeing homothallic). Nature 394, 734.

Bradshaw BP. 2005 - Physiological aspects of Corylus avellana associated with the French black truffle fungus Tuber melanosporum and the consequence for commercial production of black truffles in Western Australia. [PhD thesis], Murdoch University.

Castrignanò A, Goovaerts P, Lulli L, Bragato G. 2000 - A geostatistical approach to estimate probability of occurrence of Tuber melanosporum in relation to some soil properties. Geoderma 98, 95-113.

Chevalier G, Poitou N. 1990 - Study of important factors affecting the mycorrhizal development of the truffle fungus in the field using plants inoculated in nurseries. Agriculture, Ecosystems \& Environment 28, 75-77.

Chevalier G, Frochot H. 1997 - La Truffe de Bourgogne. Edition Pétrarque, 2002.

Cordero C, Cáceres P, González G, Quiroz K, Bravo C, Ramírez R, Caligari PDS, Carrasco B, García-Gonzales R. 2011 - Molecular tools for rapid and accurate detection of Black Truffle (Tuber melanosporum Vitt.) in inoculated nursery plants and commercial plantations in Chile. Chilean Journal of Agricultural Research 71, 488-494.

Delmas J. 1978 - Tuber spp. In S.T. Chang and WA. Hayes (eds.), The Biology and Cultivation of Edible Mushrooms. New York: Academic Press Inc.

Hall IR, Brown GT, Zambonelli A. 2007 - Taming the Truffle, the history, lore and Science of the Ultimate Mushroom. Oregon, USA: Timber Press: 22-32

Khabar L. 2011 - Ecological and phytosociological study of truffles (genus Tuber) in Morocco. In: Khabar L. (ed.), Cahier Des Resumes The $6^{\text {th }}$ International Workshop on Edible Mycorrhizal Mushrooms, April 6-10, 2011. Rabat: 60. 
Le Tacon F, Zeller B, Plain C, Hossann C, Bre'chet C, Robin C. 2013 - Carbon transfer from the host to Tuber melanosporum mycorrhizas and ascocarps followed using a 13C pulselabeling technique. PLoS ONE 8, e64626.

Linde CC, Selmes H. 2012 - Genetic diversity and mating type distribution of Tuber melanosporum and their significance to Truffle cultivation in artificially planted truffiéres in Australia. Applied Environmental Microbiology 78, 6534-6539.

Lulli L, Bragato G, Gardin L. 1999 - Occurrence of Tuber melanosporum in relation to soil surface layer properties and soil differentiation. Plant and Soil 214, 85-92.

Murat C, Díez J, Luis P, Delaruelle C, Dupré C, Chevalier G, Bonfante P, Martin F. 2004 Polymorphism at the ribosomal DNA ITS and its relation to postglacial re-colonization routes of the Perigord truffle Tuber melanosporum. New Phytologist 164, 401-411.

Napoli C, Mello A, Borra A, Vizzini A, Sourzat P, Bonfante P. 2010 - Tuber melanosporum, when dominant, affects fungal dynamics in truffle grounds. New Phytologist 185, 237-247.

O'Neill M. 2007 - Coveted, French, and now in Tennessee. http://www.nytimes.com/2007/02/28/dining/28truf.html?_r=2\&oref=slogin \& (accessed 14 November 2013).

Parladé J, De la Varga H, De Miguel AM, Sáez R, Pera J. 2013 - Quantification of extraradical mycelium of Tuber melanosporum in soils from truffle orchards in northern Spain. Mycorrhiza 23, 99-106.

Pépinière R. 2004 - Les Pépinières Robin. Saint-Laurent-du-Cros, France: Brochure: 17-18.

Rubini A, Belfiori B, Riccioni C, Arcioni S, Martin F, Paolocci F. 2011 - Tuber melanosporum: mating type distribution in a natural plantation and dynamics of strains of different mating types on the roots of nursery-inoculated host plants. New Phytologist 189, 723-735.

Shaw PJA, Lankey K, Jourdan A. 1996 - Factors affecting yield of Tuber melanosporum in a Quercus ilex plantation in southern France. Mycological Research 100, 1176-1178.

Shore R. 2013 - B.C.'s first Périgord truffle, worth up to \$2,200 per kilo, found in Abbotsford. http://www.vancouversun.com/life/first+P\%C3\%A9rigord+truffle+worth+kilo+found+Abb otsford/8155234/story.html (accessed 14 November 2013).

Suz LM, Martín, MP, Colinas C. 2006 - Detection of Tuber melanosporum DNA in soil. FEMS Microbiology Letters 254, 251-257.

Thomas PW. 2012 - The role of $\mathrm{pH}$ in Tuber aestivum syn. uncinatum mycorrhiza development within commercial orchards. Acta Mycologica 47, 161-167.

Thomas PW. 2013 - Sex: a welcome frontier in truffle cultivation. Current Research in Environmental \& Applied Mycology 3, 187-192.

Turgeman T, Sitrit Y, OferDanai O, Luzzati Y, Bustan A, Roth-Bejerano N, Kagan-Zur V, Masaphy S. 2012 - Introduced Tuber aestivum replacing introduced Tuber melanosporum: a case study. Agroforestry Systems 84, 337-343. 